\title{
Inventory Control and Financial Performance of Listed Conglomerate Firms in Nigeria
}

\author{
Folajimi Festus Adegbie ${ }^{1}$, Appolos Nudubisi Nwaobia ${ }^{1}$, Grace Oyeyemi Ogundajo $^{1} \&$ Olusoji David Olunuga ${ }^{1}$ \\ ${ }^{1}$ Department of Accounting, School of Management Sciences, Babcock University, Ilishan-Remo, Ogun State, \\ Nigeria \\ Correspondence: Grace Oyeyemi Ogundajo, Department of Accounting, School of Management Sciences, Babcock \\ University, Ilishan-Remo, Ogun State, Nigeria.
}

Received: May 1, 2020

doi:10.5430/jms.v11n2p41
Accepted: May 24, 2020

Online Published: May 30, 2020

URL: https://doi.org/10.5430/jms.v11n2p41

\begin{abstract}
Inventory constitutes the substantial portion of the cost of production of firms. Conglomerate firms faced a challenge pf dwindling return due to the huge cost of production of which inventory constitute the larger portion. Studies have shown that effective inventory management which entails forecasting, acquisition, transportation, inspection, material handling, storing, warehousing, suppliers' management and inventory security are germane in reducing the cost of production to the barest minimum and enhance the returns. This study examined the effect of inventory control (inventory procurement control, inventory security control and inventory usage control) on the financial performance of listed conglomerate firms in Nigeria. The study adopted both field and empirical survey research design. The population of the study constitutes the entire six (6) listed conglomerates as at $31^{\text {st }}$ December, 2018. The target population represent 108 staff of the finance and store sections out of which seventy-two were selected using quota sampling techniques for the administration of structure questionnaire, while total enumeration technique was used for the secondary data. The research instrument was validated by checking the constructs of the questions in the questionnaire using content validity. Cronbach Alpha reliability test was carried out and the result showed that the research instrument is reliable with an overall value of 0.988 which is greater than 0.70-0.80 threshold. 68 out of 72 administered structured questionnaire were retrieved representing $94.4 \%$ retrieved and used for the analysis. Secondary data extracted from the audited annual reports and accounts for a period of twenty-two (22) years yielding 110 unbalanced firm year observations were used. Descriptive and inferential statistics were employed for testing the hypotheses. The findings revealed that: inventory control significantly affects financial performance of listed conglomerate firms in Nigeria (Adj. $\mathrm{R}^{2}=0.873, \mathrm{~F}_{(3,65)}=10.19, \mathrm{p}<0.1$ ); inventory procurement control has significant positive effect on financial performance $\left(\beta=.628, \mathrm{R}^{2}=0.565, \mathrm{t}_{(67)}=3.494, \mathrm{p}<0.1\right)$; inventory security control exerts significant positive effect on financial performance $\left(\beta=.535, \mathrm{R}^{2}=0.706, \mathrm{t}_{(67)}=2.684, \mathrm{p}<0.1\right)$; and inventory usage control significantly and positively influence financial performance $\left(\beta=.531, \mathrm{R}^{2}=0.492, \mathrm{t}_{(67)}=2.844, \mathrm{p}<0.1\right)$. Also, inventory turnover period exerted insignificant positive effect on financial performance $\left(\beta=4.64, R^{2}=0.006, t_{(108)}=\right.$ $0.83, \mathrm{p}>0.1)$. The study concluded that inventory control significantly influence financial performance of listed conglomerate firms in Nigeria. The study recommended that management of the firm should improve on suppliers' strategic relationship and provides adequate automated security for monitoring the movements of inventory in the firm.
\end{abstract}

Keywords: financial performance, inventory procurement, inventory security, inventory usage, inventory turnover period, return on asset

\section{Introduction}

The business world is fast growing with high degree of competition among various firms across the globe to capture larger market share. This is made possible through globalization where organizations irrespective of their locations have the whole world as their target customer. Also, advancement in technology has raised customers' awareness about the existence of certain goods and service in other countries thereby making them to be sophisticated in the demand for goods and service. The exposure of customers to certain goods and services in various countries may render similar products and services of local firms useless, if the goods and services offered by those firms fall short of global standard, quality, speed of delivery and price (Thanasak \& Patricia, 2013). 
This global development has made companies in Africa, particularly Nigeria to continue to strive to meet and surpass customers' expectations in order to remain competitive. Achieving this milestone, firms requires a carefully mapped out strategies aimed at creating value for customers, keeping the business profitable and capturing larger market share. According to Raymond, Vincent, Mercy and Bellah (2015), marketing strategy, product design and packaging, reduced price, speed of delivery, good quality, and well-motivated staff members among others are formidable strategies aimed at capturing lager market share. From these strategies, it can be deduced that what give customers the required satisfaction is more of the product quality than other kinds of strategies. This is because all other strategies become successful when quality is assured. Customers are always willing to part ways with their hard-earned money only when they have the assurance that the product or services they are buying will give them the required value/satisfaction.

Vipulesh (2015) pointed out that product quality is a function of materials/inputs and the technology used in processing it. This is based on the assumption that when substandard materials are processed even with the best technology or when high quality materials are processed with poor technology, the result may not translate into the required quality. This makes materials/inventory used in production process an essential ingredient of achieving organizational objectives in terms of quality delivery and form part of business current assets which also constitutes the largest cost for manufacturing and trading organizations especially the conglomerates due to the nature of their operations (Vipulesh, 2015). Therefore, the use of some controls by firms to ensure that right quantity and quality of materials are stocked within the organization at the right time with the lowest possible cost is keen (Gbadamosi, 2016).

The use of effective inventory control technique to achieve high and sustainable financial performance is often a function of the environment within which the company operates. For instance, Timothy, Patrick, Nebat and Virginia (2013) opined that most companies in developed economies of the world such as United Kingdom, United States of America, Germany, and Japan among others operate in a highly business competitive environment as well as organized and conducive business environment than countries within Africa. The organized business environment coupled with the competitive nature of companies in the developed world make it possible for them to effectively manage their inventories on grounds that the environment supports inventory planning and control within the organizations. However, in Africa particularly Nigeria, the use of inventory control techniques to achieve high financial performance still leave much to be desired as inventory planning and control are often marred by poor competition among companies, lack of trust between inventory suppliers and the companies and within ordering and inventory handling units of an organization (Gbadamosi, 2016).

\subsection{Statement of Problem}

Conglomerates had been experiencing dwindling returns (profit) due to high cost associated with production. Every organisation has profit maximization as their main focus and one of the crucial ways of attaining this is to ensure effective cost reduction techniques. A dwindling profit can be improved when the appropriate quality of inventory is used in production thus reducing waste, enhance productivity as well as profitability. Purchasing adequate quantities of inventory in a given period helps in reducing the risk and cost associated with stock-out and obsolescence, thereby reduces cost and enhances profitability level. Also, this will enable the firm to enjoy quality discount, thus purchasing at a reduced rate, and increases profit. Likewise, the capital which could have been tied down in inventory could be invested to generate more return. Inventory control is seen as a vital mechanism in improving a dwindling profitability states experiencing in most of the companies especially the conglomerate in recent time (Akpakip, 2017).

\subsection{Objective of the Study}

This study examined inventory control as a tool for addressing performance problem in quoted conglomerate companies in Nigeria. The study achieved the following specific objectives:

i. Determine the effect of Inventory Procurement Control, Inventory Security Control, and Inventory Usage Control on financial performance of listed conglomerate companies in Nigeria.

ii. Examine the effect of inventory turnover period on financial performance of listed conglomerate companies in Nigeria.

\subsection{Research Hypotheses}

$\mathrm{H}_{\mathrm{o}} 1$ : Inventory control (Inventory Procurement Control, Inventory Security Control, and Inventory Usage Control) has no significant effect on the financial performance of listed conglomerate companies in Nigeria. 
$\mathrm{H}_{\mathrm{o}}$ 2: Inventory turnover period has no significant effect on the financial performance of listed conglomerate companies in Nigeria.

\section{Literature Review}

This section dealt with the conceptual review, underpinning theory of the study and the review of extant related literature on the relationship between inventory control and financial performance.

\subsection{Conceptual Review}

Financial Performance: This is said to be a general measure of a firm's overall financial health over a given period of time and which can be used as basis for comparison between and among similar firms in the same industry. Financial performance confirms the financial health and it is a pointer to the financial soundness and profitability of an organisation. The essence of assessing the financial health of an organization is often carried out to provide information to various organizational stakeholders. Organizational stakeholders are in myriad of numbers ranging from trade creditors, bond holders, lenders, investors, employees to management and each stakeholder has varying degrees of information needs that prompts them to keep tracking the financial performance of a company. Financial performance can be evaluated or computed with different tolls however each measure draws or depicts the diverse part of financial performance. Financial performance implies general financial wellbeing of an organisation over a given timeframe. Financial performance analysis is the way toward deciding the working and financial attributes of a firm from financial statements and it is being measured as return on assets in this study using accounting figures.

Inventory Control: The term inventory according to Kilonzo et al. (2016) consists of idle physical goods/stock of high economic value held by organizations for packaging, processing or ready for sale. The nature of inventory held by organizations together with their economic values varies from one organization to the other. That is, inventory held by an organization in form of finished goods may serve as input to other organizations. Otuya and Eginwin (2017) defined inventories as stocks of raw materials, semi-finished goods and finished goods held by business organizations to facilitate smooth production process. Ashok (2013) approached the definition of inventory from accounting perspective which he explained to mean the totality of all items of tangible property which are held by firms for sale in the ordinary course of the firms' business, for further production for such sale and processed to be made available for sale.

Inventory Control Techniques: There are various inventory control techniques that can be employed by organizations to minimize cost and by implication maximizes profit. The study has carefully selected a number of inventory controls which are grouped into their likes which will be reviewed alongside other inventory control mechanisms. The broad classifications of inventory control together with the sub-classifications are: Procurement Control (Strategic Supplier partnership and Material Requirement Planning), Inventory Security Control (Regular Stock Taking and Use of Technology) and Inventory Usage Control (Just-In- Time and Safety Stock Level).

Inventory Procurement Control: Inventories used by organizations to manufacture various products are either purchased or manufactured in-house. When materials are to be produced in-house owing to qualitative reasons, organizations may still need to buy component parts from outside thereby necessitating the need to put in place some procurement controls aimed at forecasting and determining the future inventory need, ascertaining the strength and reliability of hey suppliers, building formidable negotiation ability among others (Denisa, 2014). The Procurement Controls used in this study which will be reviewed are: Strategic Suppliers' Partnership and Material Requirement Planning. According to Timothy et al., (2013), supplier partnership is a commitment by parties such as Customers/firms and Suppliers/Vendors to establish a strategic relationship which is based on a mutually agreed win-win conditions. From this definition, the emphasis of the strategic vendor partnership hinges on good working relations between customers and suppliers through cooperation rather than confrontations. The drive for and the development of the concept 'Strategic Suppliers Partnership came up in the 1980s owing the shift of firms to Just-in-Time style of production aimed at reducing wastages, shortening delivery gestation periods (lead time), improved flexibility and simplicity in the supply of major component part by suppliers (Davood et al., 2013). Material requirement planning is an inventory control technique of working backwards from the schedule of quantities as well as specification of the need dates for finished products in a master production flow plan so as to determine the requirements for inventory components required to meet the company's master production plan (Raymond, et al., 2015). Caroline et al., (2017) argued that procurement/material requirement planning encompasses the whole process of acquiring inventory and the process starts when the firm identifies or specifies inventory needs and decide for ahead of time the procurement requirement. 
Inventory Security Control: Organizations that deal in inventory either for manufacturing purpose or for resale as finished good must strive to put in place some inventory security mechanism to avoid loss of inventories. Inventory security is necessary in every organization because of the huge organizational investment in inventory coupled the associated havoc that loss of inventory owing poor security measures may cause on production process as well as organizational financial resources. The security measures or controls will ensure that there is always a balance among procured inventory, used inventory and unused inventory at all times. Various manufacturing and mercantile organizations have to develop a well-organized and formal structure of ensuring inventory security from within the organizations (Benjamin \& Daniel, 2016). This will allow for a written down procedure on inventory security issues in organizations if inventory handlers and storage specialist have to succeed in ensuring internal inventory security (Troxell, 2015). Some of the internal inventory security practices are often laid down by the management such that procedural practices can be referred to as internal inventory loss prevention practice. According to Jolla (2014), some of the internal practices put in place by organizations in ensuring inventory security include and not limited to: Documented Record Keeping, Procedural and Sequential Stock Marking, Stock Taking, Documented Procedural Stock Audit and Surveillance and Stock Checking Procedures.

Inventory Usage Control: Organizations procure and secure inventories for onward use in manufacturing or production process. However, the utilization of inventories depends on the nature of demand facing the organization as well as the size of the company in the industry. While some organizations may just maintain inventory required to produce predetermined goods, most organizations strive to maintain buffer or safety stock to keep production going until ordered inventories are received by the organization. In this study, the inventory usage controls used are Just-in-Time and Safety/Buffer Stocks. Just-In-Time otherwise known as Zero stock inventory and production is a term used to describe organizational practices that are applied to eliminate waste of inventories with emphasis on procurement of inventories required to produce certain goods (Cynthia \& Amuhaya 2015). This implies that just in time technique is an inventory control measure whose goal is to keep just enough materials in just the right place at the right time to make a predetermined amount of products. According to Anichebe (2013), safety stock is the amount of inventories held by firms to prevent stock out such as variance in delivery date owing to extended lead time, requirement variances due to inaccurate inventory forecast, quantity delivery variances which is the disparity in requisitioned and delivered material as well as inventory price fluctuation. Going by this definition, safety inventory to be maintained by firms will have to cognizance the consumption pattern of inventories within the organization which is often determined using historical consumption records or future consumption forecast. Anichebe (2013) argued that the difficulty associated with inventory control is the determination of appropriate safety level of stock due to the unpredictable level of demand.

\subsection{Underlying Theory (Lean Inventory Theory)}

This theory was developed in Arsenal in Venice in the 1450s by Henry Ford as a result of his thoughts on integrated manufacturing process. Lean inventory theory which is an extension of Just-in-Time is an inventory control philosophy which emphasized that organizations should maintain minimum inventory in line with the requirement of production process (Eroglu \& Hofer, 2011). Lean inventory theory was pioneered by Womack (1990) which was based on the principle of maintaining reduced inventories in organization. The argument in favour of reduced or lean inventory system is that it leads to improvement in company's profitability owing to reduction in inventory carrying costs. Lean inventory theory focuses on cost minimization in organizational inventory system by taking decisions centered on manufacturing, warehousing and general supply chain (Troxell, 2015).

According to Jolla (2014) the theory (Lean) tends to build on the postulation of Economic Order Quantity (EOQ) which seeks to optimize the quantity of inventories by determining the appropriate quantities of inventory to order per time. From the foregoing, the theory brings to the fore, the possibility of being dynamic in manufacturing and operating system used to monitor inventory level as well as various items of inventories that may require different treatment. In a highly competitive environment, lean inventory theory helps firms to gain competitive advantage, capture larger market shares and make more profit since carrying excess inventories negatively affects firm's net cash flow (Nyabwanga, 2013). The lean inventory theory was adopted to give theoretical explanations to the subject matter of this study. This choice is informed by the need to examine how inventory control influences organizational performance thereby calling for a prudent approach to inventory control. Also, it helps organizations to improve the return on investment of a business through reduction in inventory held by firms and its associated carrying costs. 


\subsection{Review of Extant Related Literature}

\subsubsection{Inventory Procurement Control and Financial Performance}

With respect to procurement control and return on asset, Benjamin and Daniel (2016) established the influence of inventory control and the financial performance of agrochemical distributors and dealers in Nakuru Central Sub-County. Primary data were retrieved through questionnaire administered to one hundred (100) respondents via drop and pick method. Variables for the study are use of technology in stock record keeping and strategic suppliers' partnership (independent variables) and ROA (dependent variable). The result of the regression which was generated through SPSS showed a significant relationship between the strategic suppliers' relationship and the return on asset of the studied firms.

Kwadwo (2016) examined the impact of efficient inventory control on the profitability of Ghanaian manufacturing using cross sectional research design. Both primary and secondary data were used covering a period of sixteen (16) years (2004 - 2014) from both the annual report of four manufacturing companies listed on the Ghana Stock Exchange and via questionnaire. While both strategic suppliers' partnership and regular stock taking were used as dependent variables, ROA and NPM were employed as dependent variables. Ordinary Least Squares (OLS) was used to analyse the data and the result revealed a positive and significant relationship between strategic suppliers' partnership and profitability (NPBT). In the same vein, Timothy et al., (2013) examined the impact of inventory control practices on the financial performance of the eight sugar manufacturing companies in Kenya for a period of six (6) years (2002-2007) using lean inventory method, strategic suppliers partnership, material requirement planning and the use of technology while performance was measured by Net Profit Before Tax (NPBT) and ROA. Both survey and ex-post facto research design were employed which allowed the study to generate primary date through the use of questionnaire as well secondary data from the annual financial statements available in the year book sugar statistics of the firms. Both descriptive statistics and correlation were used to describe the inventory control practices and Correlation analysis was used to determine the nature and magnitude of the relationship between dependent and independent variables respectively. The results of the study indicate that a positive correlation exists between strategic partnership with suppliers and NPBT the result of which is statistically significant.

In addition, Cynthia and Amuhaya (2015) studied the effect of inventory control on the performance of the procurement function of sugar manufacturing companies in the western sugar belt of Kenya. The main objective of the study was to establish relationship between lean inventory system, JIT, the use of technology and strategic suppliers partnership on the performance (NPBT, ROE and ROCE) sugar manufacturing companies in the western sugar belt- Kenya. The study utilized a survey descriptive research design in carrying out the research. The research design allowed the study to generate data via a self- administered questionnaire. Data for the study were analysed using SPSS and variables were described using tables and charts. The relationship among the variables was determined through ANOVA the result of which showed a significant relationship between strategic suppliers' relationship and NPBT of western sugar companies.

Kiplagat and George (2014) investigated the role on inventory control on the performance of manufacturing firms in Kenya, a case study of new Kenya Cooperative Creameries, the study employed both suppliers strategic management and safety stock as proxies for inventory control while ROA and Net Profit were used as proxies for performance, the result of the regression showed a positive and significant relationship between strategic suppliers management and net profit.

In furtherance to the submission of Kiplagat and George (2014) is the work of Raymond et al., (2015) which examined the role of inventory control practices in the financial performance of firms in Mombasa County (textile, rolling mills and food and beverage manufacturing firms in Mombasa County) using JIT, Computerized Inventory System, Strategic Suppliers Relationship and Material Requirement Planning as proxies for inventory control practice. Also, financial performance of the studied firms was assessed using ROA, ROE and NPBT. Reliability of research instruments was tested using Split Half Reliability Test. The result of the study showed that an insignificant relationship exists between strategic suppliers' partnership and NPBT of the studied firms. This finding is in agreement with finding of Ogbo, Onekanma and Wilfred (2014) and Pawan and Bahl (2014) who also found a significant relationship between Demand management and financial performance of 7 up bottling company, Enugu plant and some Iranian companies.

Also, Kennedy, Magret and Walter (2009) examined the impact of material requirement planning, vendor managed inventory/strategic suppliers partnership and maintenance of safety stock on the ROA and operational performance of Gianchore Tea Factory. The study distributed one hundred and nineteen (119) respondents. Data for the study were analysed using descriptive and regression analysis to assess the association between the variables used in the 
study. The finding of the study reveals an insignificant relationship between vendors managed inventory/strategic suppliers' partnership and financial performance (ROA)

In furtherance to the submission of Kennedy et al., (2009) is the work of Raymond et al., (2015) which examined the role of inventory control on the financial performance of firms in Mombasa County (textile, rolling mills and food and beverage manufacturing firms in Mombasa County) using JIT, Computerized Inventory System, Strategic Suppliers Relationship and Material Requirement Planning as proxies for inventory control practice. Reliability of research instruments was tested using Split Half Reliability Test. The result of the study showed that an insignificant relationship exists between strategic suppliers' partnership and material requirement planning and ROA of the studied firms.

On the other hand, Salawati, Michael and Norlina (2012), empirically examined the relationship between inventory control practice and firm performance and capital intensity on eighty-two (82) construction firms in Malaysia for a period five (5) years (2006-2010). The study used both material requirement planning and computerized inventory system or the use of technology as proxies for independent variables while financial performance was measured by Return on Assets (ROA). The result of the correlation and regression showed significant negative relationship between material requirement planning and return on asset of the studied firms.

In the same vein, Kilonzo et al., (2016) investigated the inventory control and the financial performance of some selected manufacturing companies in Kenya. The study utilized primary data which allowed it to generate data through the use of questionnaire. The questionnaire was tested for both reliability and validity through pilot study. Variables used for the study are: Strategic suppliers' relationship, the use of technology in stock record keeping and material requirement planning as independent variables while both Return on Asset (ROA), Tobin's Q, and Return on Equity (ROE) were used as dependent variables. The study carried out a pre estimation tests on the variables such as multicolinearity and homoscedasticity tests. Both descriptive and inferential statistics were used to test the linear relationships that exist between the dependent and independent variables. The study found a positive and significant relationship between suppliers' strategic relationship and return on asset of the studied firms.

Similarly, Timothy et al., examined the impact of inventory control practices on the financial performance of the eight sugar manufacturing companies in Kenya for a period of six (6) years (2002-2007). The study used lean inventory method, strategic suppliers' partnership, material requirement planning and the use of technology while performance was measured by NPBT and ROA. Both survey and ex-post facto research design were employed which allowed the study to generate primary date through the use of questionnaire as well secondary data from the annual financial statements available in the year book sugar statistics of the firms. Both descriptive statistics and correlation were used to describe the inventory control practices and Correlation analysis was used to determine the nature and magnitude of the relationship between dependent and independent variables respectively. The results of the study indicate that a positive correlation exists between strategic partnership with suppliers and ROA the result of which is statistically significant.

Kiplagat and George (2014) investigated the role on inventory control on the performance of manufacturing firms in Kenya, A case study of new Kenya Cooperative Creameries, the study employed both suppliers strategic management and safety stock as proxies for inventory control while ROA and Net Profit were used as proxies for performance, the result of the regression showed a positive and significant relationship between strategic suppliers management and return on asset.

\subsubsection{Inventory Security Control and Financial Performance}

Kariuki (2013) studied the relationship between the factors influencing inventory control and the performance of some selected companies in Nairobi using safety stocks as proxy for inventory control while performance was measured by net profit. The regression result revealed a significant relationship between regular stocks taking and financial performance. Similarly, Cynthia and Amuhaya (2015) studied the effect of inventory control on the performance of the procurement function of sugar manufacturing companies in the western sugar belt of Kenya. The main objective of the study was to establish relationship between lean inventory system, JIT, the use of technology and strategic suppliers partnership on the performance sugar manufacturing companies in the western sugar belt- Kenya. The study utilized a survey descriptive research design in carrying out the research. The research design allowed the study to generate data via a self-administered questionnaire. Data for the study were analysed using SPSS and variables were described using tables and charts. The relationship among the variables was determined through ANOVA the result of which showed an insignificant relationship between the use of technology in inventory control and the return on equity of western sugar companies. 
Kwadwo (2016) examined the impact of efficient inventory control on the profitability of Ghanaian manufacturing using cross sectional research design. Both primary and secondary data were used covering a period of sixteen (16) years $(2004$ - 2014) from both the annual report of four manufacturing companies listed on the Ghana Stock Exchange and via questionnaire. While both strategic suppliers' partnership and regular stock taking were used as dependent variables, ROA and NPBT were employed as dependent variables. Ordinary Least Squares (OLS) was used to analyse the data and the result revealed a positive and significant relationship between regular stock taking, strategic suppliers' partnership and return on asset. Ina similar vein, Salawati et al., (2012) empirically examined the relationship between inventory control practice and firm performance and capital intensity on eighty two (82) construction firms in Malaysia for a period five (5) years (2006-2010). The study used both material requirement planning and computerized inventory system or the use of technology as proxies for independent variables while financial performance was measured by Return on Assets (ROA). The result of the correlation and regression showed significant positive relationship between the use of technology and the financial performance (ROA) of the studied firms.

Kilonzo et al., (2016) investigated the inventory control and the financial performance of some selected manufacturing companies in Kenya. The study utilized primary data which allowed it to generate data through the use of questionnaire. The questionnaires were tested for both reliability and validity through pilot study. Variables used for the study are: Strategic suppliers relationship, the use of technology in stock record keeping and material requirement planning as independent variables while Return on Asset (ROA), Tobin's q and Return on Equity (ROE) were used as dependent variables. The study carried out a pre estimation tests on the variables such as Multicolinearity and homoscedasticity tests. Both descriptive and inferential statistics were used to test the linear relationship that exists between the dependent and independent variables. The study found a positive and significant relationship between the use of technology and ROE of the studied firms.

Raymond et al., (2015) examined the role of inventory control practices in the financial performance of firms in Mombasa County (textile, rolling mills and food and beverage manufacturing firms in Mombasa County) using JIT, Computerized Inventory System, Strategic Suppliers Relationship and Material Requirement Planning as proxies for inventory control practice. Also, financial performance of the studied firms was assessed using ROE and NPBT. Reliability of research instruments was tested using Split Half Reliability Test. The result of the study showed that there is a positive and significant relationship between computerized inventory system and return on equity of the studied firms. Likewise, Egberi and Egberi (2011) examined the link between efficient inventory control and the profitability of eternity limited using a well structure questionnaire to collect data from 216 randomly selected staff. Regular stock taking and safety stock were used as independent variables while ROE was used as dependent variable. The findings of the study revealed among others that a significant relationship exists between regular stock taking and the financial performance of the studied company.

\subsubsection{Inventory Usage Control and Financial Performance}

On the alternative, Fariza, Rohaizah, Mohd and Rushami (2015) examined the inventory control practices and of some selected companies in Malaysia. Independent variables used in the study include among others JIT inventory control system while performance was measured by ROA. The study utilized primary data generated through questionnaire and was analysed using regression analysis. The study found a negative and insignificant relationship between JIT and financial performance. In the same vein, Agu et al., (2016) studied the relationship between Just in Time (JIT) and the performance of some selected companies. Primary method of data collection (questionnaire and interview) was employed by the study. The result of the tested hypothesis using regression analysis revealed that there is no significant relationship between JIT and the performance (ROCE) of the studied firms

Also, Thanasak and Patricia (2013) investigated the effect of inventory control in the food manufacturing industry in Pennsylvania, United States. Data for the study was collected through questionnaire. Also, while safety stock was used as proxy for independent variable, ROA was used as dependent variable. The study found an insignificant relationship between safety stock and financial performance which is also in agreement with the study of (Damitrios, 2008; Anichebe, 2013; Olusakin, 2014; and Caroline et al., 2017). Also, the study of Atuya and Eginiwin (2017) on inventory control and SMEs profitability in Delta state also found and insignificant relationship between demand management and SMEs profitability using both ROA and net profit.

On the other hand, Kennedy et al., (2009) examined the role of inventory control practices in the financial performance of firms in Mombasa County (textile, rolling mills and food and beverage manufacturing firms in Mombasa County) using JIT, Computerized Inventory System, Strategic Suppliers Relationship and Material Requirement Planning as proxies for inventory control practice. Also, financial performance of the studied firms was 
assessed using ROA, ROE and NPBT. Reliability of research instruments was tested using Split Half Reliability Test. The result of the study showed that an insignificant relationship exist between strategic suppliers partnership and ROE of the studied firms.

Adeyemi and Salami (2010) examined effect of inventory control on the performance of Nigeria bottling company, Ilorin plant. Both EOQ and safety stocks were used as independent variables while ROCE and NP were used to assess financial performance. The result of the Chi-square analysis showed a strong relationship exists between safety stocks and financial performance (ROCE). This finding is in agreement with submission of Enock, Georgery, Elizabeth and John (2017) and on fifteen (15) textile manufacturing firms operating in Nairobi County-Kenya as well as the finding of Alin (2016) who investigated inventory control, service level and safety stock in company's financial performance.

Contrary to foregoing findings is the work of Ashok (2013) on the relationship between safety stocks, inventory conversion periods and firms profitability measured by net operating profit in top Indian cement companies. Both primary and secondary sources of data collection were used and the results of the regression revealed that a negative and insignificant relationship exist between safety stocks and firms' profitability.

\subsection{Rationale for the Study}

The need for this study emanated from the literature gap identified from various reviews in this area, it is evidence that most studies are carried out on inventory control in Nigeria and other countries (Kilonzo et al., 2016; Cynthia and Amuhaya, 2015; Enock, et al., 2017; Caroline et al., 2017) ,had used several measures of inventory control such has just in time, material requirement planning, safety stock but none was able to combine all these variables as used in this study. This study combined inventory procurement control (IPC), inventory usage control (IUC) and inventory safety control (ISC) as measures of inventory control as against the previous research. These measures seem to be more effective as explained in the underpinning theories. Also, within the limit of empirics reviewed, no study was found in Nigerian context concentrating on a particular sector of the industry. The choice of conglomerate sector is because the companies keep large quantities of inventory due to the nature and size of their operations; thus the need for this studies.

\section{Methodology}

\subsection{Research Design}

This study employed both field and empirical survey research design. Field survey research design was employed because of the nature of data required to measure the independent variables. The information about the suppliers management, use of technology in material handling, system of stocking taking of the firm could not be derived through secondary source (annual reports), thus, the need for the adoption of primary source of data through administration of structured questionnaire. The choice of the research design is consistent with the studies of Olusakin, (2015); Caroline et al., (2017); Atuya and Eginiwin (2017). Empirical survey (expost facto) design was adopted to confirm the results obtained through the primary data and thus inventory control was measured as inventory turnover period.

\subsection{Population, Sample Size and Sampling Technique}

The scope of this study was the listed conglomerates in Nigeria. According to the Nigerian Stock Exchange records; only six (6) conglomerates are listed as at $31^{\text {st }}$ December 2018; thus this represent the population of this study. The choice of the conglomerate was determined due to the volume of inventory used by these companies based on their nature and size. All the 108 staffs of the selected conglomerate whose job description are related to inventory control were considered as respondents for this study. All the six (6) listed conglomerate firms were used for the analysis carried out using secondary data. Total enumeration sampling technique was adopted for the secondary data analysis while the study selected 12 employees from each of the six (6) conglomerates as respondents for the administration of the structured questionnaire (primary data source); this, totalled 72 respondents. The twelve (12) employees were selected purposively as employees whose duties are directly related to inventory control were selected as respondents.

\subsection{Data Collection Instrument Administration}

This study made use of both primary and secondary sources of data. The primary data were generated through the administration of structured questionnaire to the selected respondents. The respondents were 12 employees of each of the 6 conglomerate at their main offices located in Lagos. The secondary data were obtained from audited annual reports and accounts of all the six (6) listed conglomerates for a period of 22years (1997-2018) resulting into 110 
unbalanced firm year observations. The period of 22years was considered based on the years of incorporations of the firms categorized as conglomerates according to NSE.

The study generated primary data through the use of structured questionnaire which was constructed in Likert scale format. The questionnaire was structured into five different section while section A focused on the demographic characteristics of the respondent, section B to D focused on inventory control with section B on the review the effect of inventory procurement control, section $\mathrm{C}$ and $\mathrm{D}$ examined the effect of inventory security control and inventory usage control while section $\mathrm{E}$ is centred on the financial performance respectively. A total of 72 copies of the questionnaire were prepared and administered to 12 employees each whose jobs are directly linked to inventory control in each of the six (6) companies. The secondary data were obtained from annual reports and accounts of sampled firms for the periods covered.

Structured questionnaire for the study was scrutinized for both content and predictive validity and subjected to reliability test to ensure consistency using Cronbach Alpha Reliability test with the result of 0.988 being greater than the tabulated range of $.70-0.8$ reflected the reliability of the instrument. The annual reports and accounts is said to be reliable since it has been duly audited and validated by certified auditors and the opinion on the quality of the reports has been duly signed and approved. In compliance with Company and allied matter act (CAMA) sections 352 -354 for independent audit of the annual reports, and the reports of the auditors are considered to be dependable and reliable. Audited annual reports in line with the regulation gives users of the financial statement a level of confidence that the financial information presented in the financial statement are reliable and can be used to make informed economic decisions. Copies of structured questionnaire were administered to the respondents in their various offices with the help of the unit heads of the inventory procurement, stores, and the finance section which dealt with the payables control.

\subsection{Method of Data Analysis}

The data obtained from the administered questionnaire were coded and analysed using percentages and multiple regression analysis with the aid of Excel and E-views 11.0 software. While, simple linear regression model was used in investigating the effect of inventory turnover period on financial performance to corroborate the reports obtained from the analysis using primary data. The post-estimation tests were carried out; they are the heteroskedasticity test, and the serial correlation test to ensure that the model appropriately stated for the estimation and to avoid biased results. The analysis of the secondary sourced data was carried out with the aid of Stata IC. 11.0

\subsection{Model Specification and Measurement of Variables}

\section{Model Specification}

This study examined the effect of inventory control on the financial performance of listed conglomerate firms in Nigeria. The econometric model used by Enock et al., (2017) was adopted and modified which is given as follows:

$$
\mathrm{ROA}_{\mathrm{it}}=\mathrm{a}_{0}+\beta_{1} \mathrm{EOQ}_{\mathrm{it}}+\mathrm{e}_{\mathrm{it}}
$$

Where:

$\mathrm{ROA}_{\mathrm{it}}=$ Dependent Variable at time $\mathrm{t}$ (financial performance)

$\mathrm{a}_{0}$ is the constant term

$\beta_{1} \mathrm{EOQ}_{\mathrm{it}}$ represents independent variable (inventory control) and its change $\left(\beta_{1}\right)$ at time $\mathrm{t}$, and $\mathrm{e}_{\mathrm{it}}$ is the error term

However, this study's dependent variable was represented by financial performance FP while the independent variable was represented by Inventory control IC. Thus, the model of Enock (2017) was modified to formulate the model of this study as:

$$
\mathrm{FP}_{\mathrm{it}}=\mathrm{a}_{0}+\beta_{1} \text { Inventory } \text { Control }_{\mathrm{it}}+\mathrm{e}_{\mathrm{it}}
$$

The regression equation for this study as stated thus:

$$
\begin{aligned}
\mathrm{FP}_{\mathrm{i}}=\mathrm{a}_{0}+\beta_{1} \mathrm{IPC}_{\mathrm{i}}+\beta_{2} \mathrm{ISC}_{\mathrm{i}}+\beta_{3} \mathrm{IUC}_{\mathrm{i}}+\mathrm{e}_{\mathrm{i}} & \text { (using primary data); and } \\
\mathrm{ROA}_{\mathrm{it}}=\beta_{0}+\beta_{1} \mathrm{ITP}_{\mathrm{it}}+\mu_{\mathrm{it}} & \text { (using secondary data) }
\end{aligned}
$$

where: inventory control techniques are classified as: Inventory Procurement Control (IPC), Inventory Security Control (ISC) and Inventory Usage Control (IUC). Inventory Turnover Period (ITP); and Performance as: Financial Performance (FP); Return on Assets (ROA). 


\section{Measurement of Variables}

Table 1. Identification and measurements of variables

\begin{tabular}{|c|c|c|c|}
\hline \multicolumn{2}{|c|}{ Variables } & $\begin{array}{l}\text { Abbrevi } \\
\text { ation }\end{array}$ & Measurements \\
\hline \multicolumn{4}{|c|}{ Dependent Variable } \\
\hline \multicolumn{2}{|c|}{ Financial Performance } & FP & Financial Performance \\
\hline \multicolumn{2}{|c|}{ Return on Asset } & ROA & Profit After Tax/Total Asset*100\% \\
\hline \multicolumn{4}{|c|}{ Independent variables } \\
\hline \multicolumn{4}{|c|}{ Inventory Procurement Control } \\
\hline \multicolumn{2}{|c|}{ i. Strategic Suppliers Partnership } & SSP & $\begin{array}{l}\text { Measured by existence and sustainable long term relationship } \\
\text { between each company and inventory vendors. }\end{array}$ \\
\hline \multicolumn{2}{|c|}{ ii. Material Requirement Planning } & MRP & $\begin{array}{l}\text { Measure by the existence and efficiency of material forecasting } \\
\text { mechanism }\end{array}$ \\
\hline \multicolumn{4}{|c|}{ Inventory Security/ Safety Control } \\
\hline i. & Use of Technology & UT & $\begin{array}{l}\text { Existence of computer systems in stock recording system to secure } \\
\text { inventory. }\end{array}$ \\
\hline ii. & Regular stock taking & RST & $\begin{array}{l}\text { This is measured by the existence and frequency of stock taking } \\
\text { method in each company. }\end{array}$ \\
\hline \multicolumn{4}{|c|}{ Inventory Usage Control } \\
\hline i. & Just - In -Time & JIT & $\begin{array}{l}\text { Measured by Existence and maintenance of lean inventory just } \\
\text { satisfy specific production requirement. }\end{array}$ \\
\hline ii. & Safety Stock & SS & Existence, adequacy or otherwise of buffer stock. \\
\hline \multicolumn{2}{|c|}{ Inventory Turnover Period } & ITP & Average Inventory/Cost of Sales*365days \\
\hline
\end{tabular}

Source: Researcher's Work (2020)

\section{Results and Discussion of Findings}

The results of the regression analysis on the effect of inventory control on financial performance of listed conglomerates firms in Nigeria is as shown in Tables 2 and 3 respectively.

Table 2. Regression Analysis (Primary data)

\begin{tabular}{|c|c|c|c|c|}
\hline Variable & Coefficient & Std Error & t-Stat. & Prob. \\
\hline $\begin{array}{l}\text { IPC } \\
\end{array}$ & 1.822 & 0.676 & 2.697 & $0.082^{*}$ \\
\hline ISC & 0.787 & 0.166 & 4.731 & $0.053^{*}$ \\
\hline IUC & 1.060 & 0.392 & 2.702 & $0.088^{*}$ \\
\hline Constant & 2.733 & 1.244 & 2.197 & 0.772 \\
\hline Adjusted R-squared & 0.873 & & & \\
\hline F-Statistics (Prob) & $10.19(0.02 *)$ & & & \\
\hline Dependent Variable: FP & ficant at $10 \%$ & & & \\
\hline \multicolumn{5}{|c|}{ Source: Researcher's Study, (2020) } \\
\hline \multicolumn{5}{|l|}{$\mathrm{FP}=f(\mathrm{IPC}, \mathrm{ISC}, \mathrm{IUC})$} \\
\hline \multicolumn{5}{|c|}{$\mathrm{FP}_{\mathrm{i}}=\mathrm{a}_{0}+\beta_{1} \mathrm{IPC}_{\mathrm{i}}+\beta_{2} \mathrm{ISC}_{\mathrm{i}}+\beta_{3} \mathrm{IUC}_{\mathrm{i}}+\mathrm{e}_{\mathrm{i}}$} \\
\hline \multicolumn{5}{|c|}{$\mathrm{FP}=2.733+1.822 \mathrm{IPC}+0.787 \mathrm{ISC}+1.06 \mathrm{IUC}+\mu_{\mathrm{t}}$} \\
\hline
\end{tabular}




\section{Interpretation}

The result of the regression analysis testing the effect of inventory control on the financial performance as presented in Table 2 depicts that Inventory Procement Control (IPC) exerts significant positive effect on financial performance at $10 \%$ significant level $(\rho=0.082<0.1)$. The result with the coefficient of 1.822 implies that a unit increase in the inventory control would result to 1.822 increases in the firm's financial performance. It showed that as inventory control increases by a unit, financial performance of listed conglomerate firms in Nigeria would increase by 1.822; therefore, this study fails to accept the null hypothesis which states that inventory procurement control by the conglomerate does not significantly influence its financial performance the financial performance.

Similarly, it was found that Inventory Security Control (ISC) positively and significantly influence financial performance of listed conglomerate firms in Nigeria with the $\rho$-value of 0.053 being less than the chosen significant level of $10 \%$. The coefficient of the analysis with 0.787 is an indication that a unit increase in the inventory security control would result to 0.787 increases in the financial performance. This implies that as inventory security control increases by one unit, the financial performance of the listed conglomerate in Nigeria would also rise by 0.787. Therefore, this study hereby nullifies the hypothesis which states that inventory security control has no significant effect on financial performance of listed conglomerate firms in Nigeria. In conclusion, the inventory security control systems by the conglomerate have significant positive effect on the financial performance.

Looking at the coefficient and the $\rho$-value of Inventory Usage Control (IUC) in the result of the multiple regression model presented in Table 2, it was revealed that IUC has significant positive effect on the financial performance with the $\rho$-value of 0.088 being less than $10 \%$ chosen level of significance. According to the result of the coefficient of 1.060 , it means that a unit increase in the inventory usage control would result to 1.060 increases in the firm's financial performance; as the inventory usage control increases by a unit, the financial performance would also improve by 1.06 units. Therefore, this study hereby rejects the null hypothesis which states that inventory usage control has no significant effect on financial performance of listed conglomerate firms in Nigeria. Conclusively, the inventory usage control positively and significantly affects the financial performance of listed conglomerate.

Considering the combined effect of inventory control (inventory procurement control, inventory security control and inventory usage control), the probability of F-statistics of 0.02 which is less than $10 \%$ accepted significance level reflected that inventory control (inventory procurement control, inventory security control and inventory usage control), significantly influence financial performance of listed conglomerate firms in Nigeria. The coefficient of multiple determination of 0.873 implies that only 87.3 percent change or variation in financial performance could be explained by the variation in the inventory control (inventory procurement control, inventory security control and inventory usage control), while the remaining changes of 12.7 per cent is as a result of variations in other factors not captured in this model. Conclusively, this study therefore reject the null hypothesis which states that inventory control (inventory procurement control, inventory security control and inventory usage control) has no significant effect on the financial performance of listed conglomerate firms in Nigeria.

Table 3. Regression Analysis (Secondary data)

\begin{tabular}{lllll}
\hline \multicolumn{5}{l}{ MAIN MODEL (SECONDARY DATA) } \\
\hline Variable & POOLED OLS & & \\
\hline Constant & Coeff & Std.Err & t-test & Prob \\
\hline ITP & 3.02 & 1.04 & 2.92 & 0.004 \\
\hline $\mathrm{R}^{2} ;$ F-Stat (Prob) & 4.64 & 5.59 & 0.83 & 0.408 \\
\hline Hausman Test & $0.0062 ; \mathrm{F}_{(1,110)}=0.69(0.41)$ & & \\
\hline Testparm & $\mathrm{chi}_{(1)}{ }^{2}=8.22(0.004)$ & \\
\hline Heteroskedasticity Test & $\mathrm{F}_{(21,84)}=1.01(0.46)$ & \\
\hline Serial Auto-Correlation Test & $\mathrm{chi}_{(1)}{ }^{2}=0.63(0.43)$ & \\
\hline
\end{tabular}

Source: Author's Work (2020) 
Model: $\mathrm{ROA}_{\mathrm{it}}=\beta_{0}+\beta_{1} \mathrm{ITP}_{\mathrm{it}}+\mu_{\mathrm{it}}$

$\mathrm{ROA}=3.02+4.64 \mathrm{ITP}_{\mathrm{it}}$

\section{Interpretation}

The results of the Hausman test carried out to choose the best regression estimator between fixed random with $\rho$-value of 0.004 as shown in Table 3 revealed that fixed effect is the most appropriate estimator but the results of the confirmatory tests carried out using testparm test nullifies the result of the Hausman with an insignificant probability value ( $\rho$-value of 0.46 ) making the chosen fixed effect inappropriate for the estimation, thus Pooled OLS is adjudged to be the most appropriate and used for the analysis. Heteroskedasticity test carried out using Breusch-Pagan/Cook-Weisberg Test to detect if there is presence of heteroskedasticity problem, that is if the variations in the residuals of the model over the period " $\mathrm{t}$ " in both models are trending over time; with the $\rho$-value of 0.43 indicated that the variation sin the residuals of the model are constant over time, thus no presence of heteroskedasticity in the model. Likewise, the result of the serial auto-correlation carried to examine if the associations among the coefficients of the model and its residuals are unhealthy using Wooldridge test, as such would result into the error terms being smaller than normal and the co-efficient of determination being higher than expected; with the $\rho$-value of 0.81 confirm the null hypothesis of the test which implies that there is no first order autocorrelation. Based on the results of the diagnostic tests carried out; the model is being carried out using Pooled Ordinary Least Square.

\section{Regression Result}

Regression analysis was conducted to validate the result obtained through the administration of structured questionnaire and the result presented in Table 3 revealed that Inventory Turnover Period (ITP) has insignificant positive effect on financial performance (Return on Asset) with $\rho$-value of 0.408 being greater than $10 \%$ level of significance chosen for this study.

Contrary to the findings obtained from the results of the analysis conducted through primary source of data which showed a significant effect of combined inventory control mechanism on financial performance. It can be deduced that inventory value which is purely valuation of closing inventory of an entity at the end of the reporting periods could not capture all the mechanism of inventory control put in place by the management of an entity. This is the reason for the choice of primary means of data through administration of structured questionnaire which was designed to capture three key categories of inventory planning and control; that is, inventory procurement control, inventory security control and inventory usage control. Judging from the results obtained from both the primary source and secondary data, this study opined that the data obtained through the administration of structured questionnaire is more comprehensive and robust than just analysing the effect of value of closing inventory on returns of the six (6) sampled firms classified as conglomerates as used in this study.

\subsection{Discussion of Findings}

The result of the regression analysis revealed that inventory procurement control positively and significantly affects the financial performance. The finding aligns with the apriori expectations. The result of this study is consistent with the results of similar studies conducted in the past by Timothy et al., (2013) and Kilonzo et al., (2016) who also reported that strategic suppliers partnership and material requirements planning as measures of inventory procurement control had significant positive effect on the financial performance of firms while the findings negates the report of Raymond et al., (2015) which examined the role of inventory control practices in the financial performance of firms in Mombasa County (textile, rolling mills and food and beverage manufacturing firms in Mombasa County) using JIT, Computerized Inventory System, Strategic Suppliers Relationship and Material Requirement Planning as proxies for inventory control practice; and reported that an insignificant relationship exist between strategic suppliers partnership and material requirement planning and ROA of the studied firms. The result also align with the theoretical underpinning of this study, resource dependency theory and the assertion of Kitaeva (2014) which state that the long term customer-supplier relationship, organizations will be able to shield itself from both internal and external organizational as well as environmental changes and achieve optimal level of inventory control.

The finding of this study revealed that inventory security control has significant positive effect on the financial performance. This finding corroborates the reports of Kariuki (2013) who obtained a significant relationship between regular stocks taking and financial performance; likewise, the report of Raymond et al., (2015) of positive and significant relationship between computerized inventory system and return on equity of the studied firms. Also, Kilonzo et al., (2016); Salawati et al., (2012) showed significant positive relationship between the use of technology and the financial performance (ROA) of the studied firms. On the contrary, Cynthia and Amuhaya (2015) showed an 
insignificant relationship between the use of technology in inventory control and the return on equity of western sugar companies.

The result also aligns with the theoretical underpinning of this study, lean inventory production theory which is based on the principle of maintain reduced inventories in organization. It premised on the assertion that cost optimization in organizational inventory system by taking decisions that borders manufacturing, warehousing and general supply chain improves the performance (Troxell, 2015).

The finding of this study depicted that inventory usage control positively and significantly influences the financial performance of listed conglomerate firms in Nigeria. The finding contradicts the report of Fariza et al., (2015) which found an insignificant negative relationship between JIT and financial performance; while Agu et al., (2017) reported that no significant relationship exist between JIT and the performance (ROCE) of the studied firms. In similar vein, Thanasak et al., (2013) found an insignificant relationship between safety stock and financial performance. The finding supported the assertions of Adeyemi and Salami (2010) that examined effect of inventory control on the performance of Nigeria bottling company, Ilorin plant and reported a strong relationship exists between safety stocks and financial performance (ROCE); and Enock, et al. (2017) as well as Akin (2016) who investigated inventory control, service level and safety stock in company's financial performance. The finding of this study also align with the underlying theory as lean inventory theory believed to reduce excess buffer stocks as well inventory wastage and this allows for flexibility in manufacturing process by reducing the stock of inventory and inventory carrying cost.

\subsection{Implication of Findings}

The result of this study revealed that the management of the firms has placed stringent rules to ensure that inventory cost is reduced to the barest minimum, thus improve the reported profit. Looking beyond the conventional checking of financials in relation to inventory control has exposed the management to several other means of placing stringent planning and controls in respect to inventory thereby resulting to reduction in inventory cost as well as cost of production as a whole. Also, this study has shown that inventory control goes beyond inventory recording and therefore, practitioners as auditors, consultants should dig deep beyond financial records in executing their duties in terms of inventory audit, planning and control so as to give effective advice to the management of the firms in question.

\section{Conclusion and Recommendations}

This study examined the effect of inventory control (inventory procurement control, inventory security control and inventory usage control) on the financial performance of listed conglomerate firms in Nigeria. Numerical description of all variables under study was captured to depict the movement of values and determine the fluctuations of each of the independent variables with the dependent variables. Based on the result of the multiple regression analysis carried out, this study concluded that inventory control (inventory procurement control, inventory security control and inventory usage control), have significant on the financial performance of listed conglomerate firms in Nigeria. Based on the findings and conclusions of this study, it is recommended that:

Management should improve in their communication with the suppliers; hold regular meetings with the suppliers to disseminate important issues relating the inventory procurement; the management should strive to maintain good suppliers' chain management of inventory to avoid pilferage; and the management should ensure that adequate security is in place to enforce restrictions on unauthorized access to the inventory

\section{Contribution to Knowledge}

This study has made the following contributions to knowledge.

\subsection{Contribution to Concept}

This study seemed to be the first study to use variables as suppliers' management, stock taking processes, restriction of authorization, Just-In -Time, and material requirement planning for measuring inventory control (inventory procurement control, inventory security control and inventory usage control) other than the conventional yardstick of inventory turnover period and inventory turnover ratio especially on the listed conglomerate firms in Nigeria.

\subsection{Contribution to Literature}

This study has also contributed to the existing literature by attempting to form a nexus between the independent variables and dependent variables. Also, the study contributes to existing literature through the models developed and supported with the underlining theories of the study. This study has contributed to the existing literature by the findings that have been examined; implications of the findings, the recommendations that have been made. 


\subsection{Contribution to Policy}

The study is of immense benefit to the management of the corporate bodies by designing alternative measures of determining the effect of inventory control on the firm performance financially using strategies of inventory procurement control, inventory security control and inventory usage control, other than traditional measures of evaluating inventory as inventory turnover period and inventory turnover ratio.

\subsection{Contribution to Practice}

This study has shown that inventory control goes beyond inventory recording and therefore, enlightens the practitioners as auditors, and consultants to go far beyond financial records in executing their duties in terms of inventory audit, planning and control so as to give effective advice to the management of the firms in question.

\subsection{Contribution to Theory}

This study has laid credence to lean inventory theory. It has added to the wide acceptability of the theory especially in testing the effect of inventory control on financial performance of conglomerate firms in Nigeria. This theory is built on the postulation of Economic Order Quantity (EOQ) which seeks to optimize the quantity of inventories by determining the appropriate quantities of inventory to order any time an order is to be placed. Thus, the theory brings to the fore, the possibility of being dynamic in manufacturing and operating system used to monitor inventory level as well as various items of inventories that may require different treatment. In a highly competitive environment where the conglomerate firm operates, lean inventory theory helps firms to gain competitive advantage, capture larger market share and make more profit since carrying excess inventories negatively affects firm's net cash flow (Nyabwanga, 2013).

\section{References}

Adeyemi, S. L., \& Salami, A. O. (2010). Inventory control: A tool of optimizing resources in manufacturing industry: a case study of Coca-cola bottling company, ilorin plant. Journal of Social Sciences , 23(2), 135-142.

Agu, O. A., Anike, H. O., \& Eke, C. N. (2016). Effect of inventory control on the organizational performance of the selected manufacturing firms. Singaporean Journal of Business, Economics and Management Studies, 5(4), 17-32.

Akpakip, C. E. (2017). Effect of work force diversity of employee performance in Nigerian banking industry. A study of First Bank of Nigeria Ltd. Ota branch. Research work at Convenant University Ota Nigeria.

Alin, C. (2016). Inventory control, service level and safety stock. Journal of Public Administration, Finance and Law, 6(1), 145-152.

Anichebe, N. A. (2013). Effect of inventory control on organizational effectiveness and performance. Journal of Information and Knowledge Management, 2(8), 171-187.

Ashok, K. P. (2013). Relationship betwen inventory control and profitability: an empirical analysis of indian cement companies. Asia Pacific Journal of Marketing and Management Review, 2(7), 129-136.

Atuya, S., \& Eginiwin, E. J. (2017). Inventory control and SMEs profitability: a study of furniture manufacturing and wholesale industry, Delta state. Journal of Finance and Accounting, 5(3), 75-79.

Benjamin, N. O., \& Daniel, M. O. (2016). Influence of inventory control practice on procurement and performance of agro-chemicals distributors in Nakiru central sub-county, Kenya. Internatioinal Journal of Economics, Finance and Management Sciences, 4(3), 117-126.

Caroline, A. O., Willy, M., \& Wallace, A. (2017). Effect of inventory control methods on the performance of procurement function in sugar manufacturing firm in western Kenya. International Journal of Social Sciences and Information Technology, 3(2), 13-27.

Cynthia, M. M., \& Amuhaya, M. I. (2015). An analysis of of the effect of inventory control on the performance of procurement function of sugar manufacturing companies in the western Kenya sugar belt. International Journal of Scientific and Research Publication, 5(5), 87-94.

Damitrios, P. K. (2008). The effect of inventory control on firm performance. International Journal of Productivity and Performance Management, 57(5), 355-369.

Egberi, K. A., \& Egberi, E. O. (2011). Inventory control and management as effective and efficient tools in achieving organizational growth in Nigeria: a case study of eternit limited, sapele, Delta. International Journal of Economic Development Research and Investment, 2(2), 67-98. 
Enock, G. M., Gregory, N., \& Elizabeth, N. M. (2017). The effect of inventory control on organizational performance among textile manufacturing firms in Kenya. International Journal of Academic Research in Business and Social Sciences, 7(11), 1-21.

Eroglu, C., \& Hofer, C. (2011). Lean, leaner, too lean? the inventory performance. Journal of Operations Management, 1(1), 356-369.

Fariza, A. M., Rohaizah, S., Mohammed, M. M., \& Rushami, Z. Y. (2015). The influence of inventory control practices towards inventory control performance in malaysian public hospitals. International Academic Research Journal of Business and Technology, 1(2), 142-148.

Fariza, A., Rushami, Z. Y., \& Roheiza, S. (2015). Inventory control practice: a key success towards supply chain performance among industries in Malaysia. 4th International conference on technology and operations management.

Gbadamosi R. A. (2016). Effectiveness of inventory control in a manufacturing company. (A case study of AMA Greenfielg breweries plc Enugu). M.Sc Dessertation, Enugu State University. Retrieved June 17, 2019, from https://www.academia.edu/5611380/EFFECTIVENESS_OF_INVENTORY_MANAGEMENT_IN_A_MANU FACTURING_COMPANY

Jolla, G. (2014). Internal Control Practice: Purchasing. Retrieved November 2018, from http://blinkuasd.edu/finance/accountability/control/practice/purchasing

Kennedy, M. M., Margeret, O., \& Walter, O. (2009). Effect of inventory control system on operational performance of tea processing firms: A case study of crianchore tea factory, nyamira County, Kenya. The International Journal of Business and Management, 1(5), 1-7.

Kilonzo, J. M., Memba, F. S., \& Njeru, A. (2016). Effect of inventory control on financial performance of firms funded by government venture capital in Kenya. European Journal of Business Management, 8(5), 181-197.

Kiplagat, K. K., \& George, O. (2014). Role of inventory control on performance of manufacturing firms in Kenya: a case of new kenya cooperative creameries. European Journal of Business Management, 2(1), 66-87.

Kitaeva, A. S. (2014). Diffusion Approximationin Inventory control with Examoles of Application: Tomsk. National Research Tomsk Polytechnic University.

Kwadwo, B. P. (2016). The impactct of efficient inventory control on profitability: evidence from selected manufacturing firms in Ghana. International Journal of Finance and Accounting, 5(1), 22-26.

Nyabwanga, R. N. (2013). Inventory control practice and business performance for small-scale enterprises in Kenya. Journal of Business for Small Scale Enterprises, 4(1), 11-28.

Ogbo, A. I., Onekanma, I. V., \& Wilfred, I. U. (2014). The impact of effective inventory control management on organizational performance: a case study of 7 up bottling company Enugu Nigeria . Mediteranean Journal of Social Sciences, 5(10), 27-41.

Olusakin, S. A. (2014). The role of raw material management in production operation. International Journal of Managing Value and Supply Chain, 5(3), 71-86.

Pawan, K., \& Bahl, R. N. (2014). Effect of inventory control on organizational performance. International Journal of Innovative Science, Engineering and Technology, 1(4), 109-121.

Raymond, M. M., Vincent, O. O., Mercy, W. M., \& Bellah, C. (2015). Role of inventory control practices on the performance of production department: a case of manufacturing firms. International Journal of Economics, Commerce and Management, 3(5), 111-127.

Salawati, S., Michael, T., \& Norlina, K. (2012). Inventory control in malaysian construction firms: Impact of performance. SIU Journal of Management, 2(1), 81-93.

Thanasak, R., \& Patricia, W. (2013). Impact of inventory inaccuracy on the food manufacturing industry. Journal of Business Management Dynamics, 2(10), 28-34.

Timothy, L., Patrick, B. O., Nebat, G. M., \& Virginia, K. W. (2013). The impact of inventory control practices on financial performance of sugar manufacturing firms in Kenya. International Journal of Business, Humanities and Technology, 3(5), 33-48.

Troxell, L. (2015). UCSC Practices for HIPPA Security Rules Compliance. Calofonia: University of Calofonia.

Vipulesh, S. (2015). Impact of inventory control on the financial performance of the firms. Journal of Business Management, 17(4), 1-12. 